DOI: https://doi.org/10.24127/ajpm.v8i2.1954

\title{
PENGEMBANGAN PERANGKAT PEMBELAJARAN BERBASIS REALISTIC MATHEMATICS EDUCATION PADA MATERI ARITMATIKA SOSIAL
}

\author{
Dwi Ivayana Sari ${ }^{1}$, Nurmawati Sari ${ }^{2}$ \\ 1,2Pendidikan Matematika, STKIP PGRI Bangkalan \\ E-mail: $\quad$ dwiivayanasari@yahoo.com ${ }^{1)}$ \\ nurmawatisari97@gmail.com ${ }^{2}$
}

Received 29 April 2019; Received in revised form 30 October 2019; Accepted 4 November 2019

\begin{abstract}
Abstrak
Penelitian ini bertujuan untuk pengembangan alat pembelajaran dalam bentuk RPP, LKS dan THB berbasis Pendidikan Matematika Realistis. Subjek dalam penelitian ini adalah 22 siswa di MTS Sirajul Huda. Desain penelitian yang digunakan adalah model empat D yang dikembangkan oleh Thiagarajan, Semmel \& Semmel. Tahap pengembangan yang hanya terdiri dari tiga tahap yaitu, mendefinisikan, mendesain, mengembangkan. Instrumen dalam penelitian ini menggunakan validasi pembelajaran, kemampuan guru mengelola pembelajaran, aktivitas siswa, respons siswa, dan hasil tes pembelajaran. Hasil dan instrumen dianalisis secara deskriptif untuk menjawab tujuan peneliti. Hasil kumpulan perangkat pembelajaran berdasarkan RME dalam materi aritmatika sosial valid. Setelah alat pembelajaran direvisi berdasarkan masukan dari validator, dan telah diuji di lapangan, kemampuan guru untuk mengelola pembelajaran berada dalam kategori efektif, aktivitas siswa dalam kategori baik, angket respon siswa adalah kategori baik, dan validitas, sensitivitas, dan keandalan item di dalam kategori baik. Sebagai kesimpulan, alat pembelajaran ini dapat digunakan oleh guru untuk bertemu siswa sebagai pendukung implementasi kurikulum 2013.
\end{abstract}

Kata kunci: Aritmatika Sosial; Pendidikan Matematika Realistik; pengembangan.

\begin{abstract}
This research aims to development of learning tools in the form of RPP, LKS and THB based of Realistic Mathematic Education. Subjects in this reasearch were 22 students in MTS Sirajul Huda. The research design used is four D model develope by thiagarajan, semmel \& semmel. Development stage wich only consist of three stages namely, define, design, develop. Instrument in this study were using learning validation, the ability of teachers to manage learning, student activities, student responses and tes result learning. The results and instruments are analyzed descriptively to answer the purpose of the researcher. The result of the assemblage of learning devices based on RME in social arithmetic material is valid. After the learning tool has been revised based on input from the validator, and has been tested in the field, the ability of the teacher to manage the learning is in the effective category, the student activity is in good category, the student response questionnaire is good category, and the validity, sensitivity and reliability on the item inside good category. In conclusion, this learning tool can be used by teachers to meet students as supporting the implementation of curriculum 2013.
\end{abstract}

Keywords: development; realistic mathematics education;Social Arithmetics.

\section{PENDAHULUAN}

Pendidikan memiliki peranan penting dalam menyiapkan Sumber Daya Manusia (SDM) untuk membangun bangsa ini (Musyaddad, 2013). Namun, kualitas pendidikan di Indonesia masih rendah. Hal inilah yang menjadi salah satu penyebab
Indonesia pada saat ini masih masuk ke dalam kategori negara yang tertinggal dan tidak dapat mengatasi daya saing pada zaman yang modern ini.

Akan tetapi, seiring dengan perkembangan Ilmu Pengetahuan dan Teknologi (IPTEK), para pendidik harus melakukan pembaharuan di 
bidang pendidikan guna meningkatkan SDM sebagai penunjang dalam kehidupan sehari-hari. Menurut Murtiyasa (2015) paradigma baru menuntut pembelajaran berpusat pada siswa, interaktif, bersifat menyelidiki, bersifat realistis, berbasis tim (kooperatif) dan alat multimedia dengan memanfaatkan berbagai teknologi pendidikan.

Berbicara mengenai IPTEK, matematika merupakan ilmu dasar yang mempunyai peranan penting dalam perkembangan IPTEK. Selain itu, penerapan dan pemanfaatan konsepkonsep dalam matematika sangat mendukung aktivitas manusia dalam kehidupan sehari-hari (Sarismah, 2012). Oleh karena itu, kualitas pembelajaran matematika harus ditingkatkan untuk dapat mencapai perkembangan IPTEK dan kemampuan pemahaman konsep yang diharapkan.

Salah satu materi dalam matematika yang membahas mengenai aktivitas manusia dalam kehidupan sehari-hari adalah aritmatika sosial. Hal ini karena aritmatika sosial merupakan cabang ilmu matematika yang membahas hal-hal dalam kehidupan sehari-hari, seperti menghitung nilai keseluruhan, nilai per unit, dan nilai sebagian serta harga beli, harga jual, untung, rugi diskon (rabat), bruto, tara dan netto.

Berdasarkan hasil studi awal di MTs Sirajul Huda, pelaksanaan pembelajaran materi aritmatika menggunakan metode konvensional, yaitu guru menjelaskan materi, kemudian memberi contoh dan siswa mengerjakan latihan yang diberikan oleh guru. Dalam pelaksanaan pembelajaran ini, siswa terlihat pasif dan pemhaman siswa relatif rendah. Berdasarkan hasil wawancara dengan guru kelas, persentase ketuntasan belajar siswa secara klasikal di kelas hanya mencapai $60 \%$. Hal ini menunjukkan ketuntasan belajar siswa secara klasikal masih rendah.

Salah satu faktor penyebab munculnya masalah di atas adalah metode pembelajaran yang digunakan oleh guru kurang tepat. Metode pembelajaran konvensional kurang memberikan kesempatan pada siswa untuk berperan secara aktif dalam proses pembelajaran dan berpikir. Oleh karena itu, perlu adanya suatu metode yang harus digunakan oleh guru, terutama dalam mengajarkan materi aritmatika sosial.

Pembelajaran dengan pendekatan Realistic Mathematics Education (RME) merupakan salah satu pembelajaran yang tepat untuk mengajarkan materi aritmatika sosial. Hal ini dikarenakan pembelajaran RME diawali dengan penyajian masalah yang berkaitan dengan kehidupan sehari-hari siswa. Penyajian masalah ini memiliki maksud agar siswa memahami bahwa aktivitas sehari-harinya berhubungan erat dengan matematika. Hal ini sejalan dengan pendapat Simanulang (2013) yang menyatakan bahwa pendekatan realistik adalah suatu inovasi dalam pembelajaran matematika yang diperkenalkan dan dikembangkan oleh Institute Freudenthal yang mengungkapkan bahwa matematika harus dikaitkan dengan realita dan matematika adalah aktivitas manusia. Lebih lanjut Ningsih (2013:180) berpendapat bahwa melalui pembelajaran dengan menggunakan pendekatan RME, guru dapat menyusun kegiatan kelas yang memungkinkan siswa akan saling berdiskusi, berdebat, menemukan ide-ide, konsep dan ketrampilan yang membuat siswa memahami ide, konsep dan ketrampilan tersebut. Pada proses pembelajaran ini 
siswa akan memperoleh pengalaman sendiri untuk menanamkan ide, konsep dan ketrampilan tersebut di dalam memori jangka panjang.

Pelaksanaan proses pembelajaran sangatlah didukung oleh persiapan yang matang oleh seorang pendidik. Salah satu persiapan yang harus dilakukan adalah menyediakan perangkat pembelajaran. Perangkat pembelajarann ini terdiri dari Rencana Pelaksanaan Pembelajarna (RPP), Lembar Kerja Siswa (LKS) dan Soal Tes Hasil Belajar (THB). Oleh sebab itu, untuk melaksanakan pembelajaran RME, maka harus tersedia perangkat pembelajaran yang berbasis RME. Namun, di MTs Sirajul Huda perangkat pembelajaran berbasis RME belum tersedia.

Pengembangan perangkat pembelajaran sangatlah penting untuk meningkatkan kualitas pembelajaran. Hal ini dikarenakan menurut Sari \& Hermanto (2017) pengembangan perangkat pembelajaran harus disesuaikan dengan tingkat pengetahuan dan pengalaman siswa. Sehingga perangkat pembelajaran yang digunakan di suatu sekolah berbeda dengan sekolah lainnya, salah satunya bergantung pada latar belakang siswa. Di samping itu, pengembangan perangkat pembelajaran harus disesuaikan juga dengan kurikulum yang berlaku pada saat itu. Karena saat ini kurikulum yang dipakai adalah kurikulum 2013 maka pengembangan perangkat pembelajaran yang harus dikembangkan adalah perangkat pembelajaran yang sesuai dengan kuruikulum 2013. Namun pada kenyatannnya sebagian guru saat ini tidak mengembangkan perangkat pembelajaran dikarenakan mereka beranggapan bahwa bahan ajar yang sudah ada seperti buku atau LKS sudah cukup.

Berkaitan dengan pengembangan perangkat pembelajaran berbasis RME, Murwaningsih, Astutiningtyas \& Rahayu (2014) telah mengembangkan perangkat pembelajaran matematika realistik pada materi aljabar di kelas VII SMP ini yang berupa:(1) Rencana Pelaksanaan Pembelajaran (RPP); (2) Buku Siswa; (3) Lembar Kerja Siswa (LKS); (4) Buku Petunjuk Guru (BPG) dan (5) Perangkat Tes Hasil Belajar Siswa. Semua perangkat pembelajaran tersebut, setelah: (1) divalidasi ahli; (2) direvisi berdasarkan: penilaian, koreksi dan saran perbaikan para ahli; (3) dilakukan uji keterbacaan dan simulasi RPP tertentu; (4) direvisi berdasarkan analisis data hasil uji keterbacaan dan simulasi RPP tertentu; (5) dilakukan uji coba di kelas; dan (6) direvisi berdasarkan analisis data hasil uji coba, adalah baik atau valid. Sedangkan Azizah (2017) telah mengembangkan Lembar Kerja Peserta Didik (LKPD) pada materi aritmatika sosial berbasis komik. Pengembangan LKPD ini dilakukan dengan menggunakan model Thiagarajan. Begitu pula dengan hasil penelitian sebelumnya oleh Sari (2015) yang telah menggunakan model pengembangan Thiagarajan (4D) yang dimodifikasi untuk mengembangkan perangkat pembelajaran berbasis kooperatif dengan pendekatan struktural TPS untuk materi persamaan kuadrat di kelas X SMA. Hasil penelitian ini menghasilkan perangkat pembelajaran yang baik dan valid.

Berdasarkan penjelasan yang telah dipaparkan, maka dikembangkan perangkat pembelajaran berbasis RME untuk mengajarkan materi aritmatika sosial. Dengan demikina, tujuan penelitian ini adalah mengembangkan perangkat pembelajaran berupa RPP, 
LKS dan Soal THB berbasis RME yang baik pada materi aritmatika sosial dengan menggunakan model 4D yang dimodifikasi. Hasil pengembangan perangkat ini dapat dijadikan salah satu referensi bagi para praktisi untuk mengajarkan aritmatika sosial dengan menggunakan pendekatan RME.

\section{METODE PENELITIAN}

Pengembangan

perangkat pembelajaran ini mengacu pada model 4-D (four D model) yang dikembangkan oleh Thiagarajan, Semmel \& Semmel dalam Sari \& Hermanto (2017). Model ini dipilih karena sistematis dan cocok untuk mengembangkan perangkat pembelajaran berbasis RME. Beberapa modifikasi yang dilakukan antara lain sebagai berikut:

1. Penyederhanaan tahap pengembangan yang hanya terdiri dari tiga tahap, yaitu:

pendefinisian (define),

perencanaan (design), dan (3) pengembangan (develop). Jadi tidak sampai pada tahap penyebaran (disseminate) karena sampai pada tahap 3 sudah bisa dihasilkan perangkat yang dikehendaki.

2. Penyusunan THB dilakukan bersama-sama dengan design awal perangkat pembelajaran yang lain, karena THB pada penelitian ini termasuk dalam perangkat pembelajaran.

3. Pada tahap pendefinisian (define) terdapat dua hal yang dimodifikasi, yaitu:

a. Istilah analisis konsep diganti dengan analisis materi. Ini dilakukan karena materi memiliki cakupan yang lebih luas dari pada konsep.

b. Analisis materi dan analisis tugas yang semula dilakukan bersamaan diubah urutannya, yaitu analisis materi terlebih dahulu baru kemudian dilanjutkan dengan analisis tugas. Hal ini dikarenakan pemberian tugas bergantung pada materi yang akan dipelajari.

Subjek dalam penelitian ini adalah siswa MTS Sirajul Huda yang berjumlah 22 siswa untuk mengujicobakan perangkat yang dikembangkan.

Dalam rangka mengumpulkan data ujicoba, digunakan instrumen yang diadopsi dari hasil penelitian Sari \& Hermanto (2017) antara lain:

a. Lembar Validasi Perangkat Pembelajaran

Draft I yang divalidasi oleh para validator dikatakan valid jika ratarata skor yang diberikan validator berkategori baik atau sangat baik.

Adapun kategori rata-rata skor adalah sebagai berikut:

$1,00 \leq$ Rata-rata $\leq 1,50$ : sangat tidak baik

$1,50<$ Rata-rata $\leq 2,50$ : tidak baik

$2,50<$ Rata-rata $\leq 3,50$ : baik

$3,50<$ Rata-rata $\leq 4,00$ : sangat baik

b. Lembar Pengamatan Kemampuan

Guru Mengelola Pembelajaran

Kemampuan guru mengelola pembelajaran dikatakan efektif jika skor dari setiap aspek untuk semua RPP yang dinilai minimal 3. Dengan demikian hasil analisis data yang tidak memenuhi salah satu kategori baik atau sangat baik pada penelitian ini akan dijadikan bahan pertimbangan untuk merevisi perangkat pembelajaran yang telah diujicoba.

c. Lembar Pengamatan Aktivitas Siswa

Data hasil pengamatan aktivitas siswa selama kegiatan 
DOI: https://doi.org/10.24127/ajpm.v8i2.1954

$$
\begin{aligned}
& \text { pembelajaran berlangsung } \\
& \text { dianalisis dengan menggunakan } \\
& \text { persentase. Persentase pengamatan } \\
& \text { aktivitas siswa yaitu: } \\
& \text { Persentase aktivitas siswa } \\
& =\frac{\text { Frek. setiap aspek pengamatan }}{\text { Jumlah frek. semua aspek pengamatan }} \times 100 \%
\end{aligned}
$$

Penentuan kesesuaian aktivitas siswa berdasarkan pada pencapaian waktu ideal yang ditetapkan dalam

\begin{tabular}{|c|c|c|}
\hline No & Aspek Pengamatan & $\begin{array}{l}\text { Toleransi } \\
\text { Keefektifan } \\
(\%)\end{array}$ \\
\hline 1 & $\begin{array}{l}\text { Memperhatikan } \\
\text { penjelasan guru dan } \\
\text { bertanya. }\end{array}$ & $\begin{array}{c}17.82- \\
19,82\end{array}$ \\
\hline 2 & Membentuk kelompok & $5,94-6,56$ \\
\hline 3 & Menerima LKS & $5,94-6,56$ \\
\hline 4 & $\begin{array}{l}\text { Mengamati dan } \\
\text { mencermati permasalahan } \\
\text { yang terdapat pada LKS. }\end{array}$ & $4,75-5,3$ \\
\hline 5 & $\begin{array}{l}\text { Menyelesaikan } \\
\text { permasalahan atau tugas } \\
\text { pada LKS }\end{array}$ & $\begin{array}{c}17,82- \\
19,82\end{array}$ \\
\hline 6 & Siswa berdiskusi & $\begin{array}{c}23,75- \\
26,25\end{array}$ \\
\hline 7 & $\begin{array}{l}\text { Siswa mempresentasikan } \\
\text { hasil pekerjaannya }\end{array}$ & $19-21$ \\
\hline 8 & $\begin{array}{l}\text { Perilaku yang tidak } \\
\text { relevan dengan kegiatan } \\
\text { pelajaran }\end{array}$ & $0-5$ \\
\hline
\end{tabular}
penyusunan Rencana Pelaksanaan Pembelajaran (RPP) seperti pada Tabel 1.

Tabel 1. Kriteria batas efektifitas aktivitas siswa dalam pembelajaran

Aktivitas siswa dikatakan efektif dalam pembelajaran, jika 8 aspek aktivitas siswa untuk setiap pertemuan berada dalam kriteria batasan efektif dengan batas toleransi $10 \%$ dari waktu ideal. Apabila aktivitas siswa tidak memenuhi kriteria keefektifan maka akan dijadikan bahan pertimbangan untuk merevisi perangkat pembelajaran.

d. Angket Respon Siswa

Data tentang respons siswa yang diperoleh melalui angket dianalisis dengan menggunakan persentase. Persentase dari setiap respon siswa dihitung dengan berikut:

Jml respon positif siswa tiap aspek yang muncul Jml seluruh siswa

Respon siswa dikatakan positif jika jawaban siswa terhadap pernyataan adalah positif untuk setiap aspek yang direspon pada setiap komponen pembelajaran diperoleh persentase $\geq 80 \%$. Sedangkan jika persentase yang diperoleh kurang dari $80 \%$, maka perangkat pembelajaran akan dipertimbangkan untuk direvisi.

e. Tes Hasil Belajar (THB).

Salah satu teknik yang digunakan untuk menentukan validitas suatu tes adalah dengan mengkorelasikan skor yang diperoleh pada setiap butir dengan skor total. Rumus yang digunakan adalah rumus korelasi product moment, yaitu:

$$
=\frac{\mathrm{N} \sum X Y-\left(\sum X\right)\left(\sum Y\right)}{\sqrt{\left(N \sum X^{2}-\left(\sum X\right)^{2}\right)\left(N \sum Y^{2}-\left(\sum Y\right)^{2}\right)}}
$$

(Sari \& Hermanto, 2017)

\section{Keterangan:}

$r_{X Y}=$ koefisien korelasi antara skor butir dan skor total

$$
\begin{aligned}
& \mathrm{X}=\text { skor butir } \\
& Y=\text { skor total } \\
& \mathrm{N}=\text { banyaknya peserta tes }
\end{aligned}
$$

Nilai $r_{X Y}$ diinterpretasikan sebagai berikut:

$0,80 \leq r_{X Y} \leq 1,00$ : sangat tinggi

$0,60 \leq r_{X Y} \leq 0,79$ : tinggi

$0,40 \leq r_{X Y} \leq 0,59:$ cukup

$0,20 \leq r_{X Y} \leq 0,39:$ rendah

$0,00 \leq r_{X Y} \leq 0,19$ : sangat rendah 
Dalam penelitian ini, butir tes valid jika mempunyai validitas cukup, tinggi, atau sangat tinggi. Sedangkan butir tes yang mempunyai validitas rendah dan sangat rendah akan direvisi.

Rumus yang digunakan untuk menganalisis reliabilitas tes ini adalah rumus yang sesuai dengan tes bentuk uraian (essay), yaitu rumus Alpha sebagai berikut:

$$
r_{11}(\alpha)=\left(\frac{n}{n-1}\right)\left(1-\frac{\sum \sigma_{i}^{2}}{\sigma_{i}^{2}}\right)
$$

(Sari \& Hermanto, 2017)

Keterangan:

$$
\begin{array}{ll}
\mathrm{r}_{11}(\alpha) & =\text { reliabilitas tes } \\
\mathrm{n} & =\text { banyak butir soal } \\
\sum_{\mathrm{i}} \sigma_{\mathrm{i}}^{2} & =\text { jumlah varians tiap-tiap } \\
\text { item } & \\
\sigma_{\mathrm{i}}^{2} & =\text { varians total }
\end{array}
$$

Koefisien reliabilitas tes diinterpretasikan sebagai berikut: $0,80 \leq \mathrm{r}(\alpha) \leq 1,00$ : sangat tinggi $0,60 \leq r(\alpha) \leq 0,79$ : tinggi $0,40 \leq \mathrm{r}(\alpha) \leq 0,59$ : cukup $0,20 \leq r(\alpha) \leq 0,39$ : rendah $0,00 \leq \mathrm{r}(\alpha) \leq 0,19$ : sangat rendah

Dalam penelitian ini, butir tes reliabel jika mempunyai reliabilitas cukup, tinggi atau sangat tinggi. Sedangkan butir tes yang mempunyai reliabilitas rendah dan sangat rendah akan direvisi. Sensitivitas tes adalah ukuran seberapa baik butir tes itu dapat membedakan tingkat kemampuan siswa sebelum menerima pembelajaran dan sesudah menerima pembelajaran. Untuk menentukan sensitivitas butir tes digunakan rumus:

$$
S=\frac{\sum S_{e s}-\sum S_{e b}}{N\left(\text { skor }_{\max }-\text { skor }_{\min }\right)}
$$

(Sari \& Hermanto, 2017)
Keterangan:

$\mathrm{S}=$ indeks sensitivitas

$\mathrm{N}=$ banyaknya peserta tes

$\sum S_{e s}=$ jumlah skor subjek setelah proses pembelajaran

$\sum S_{e b}=$ jumlah skor subjek sebelum proses pembelajaran skor $_{\max }=$ skor maksimum yang dicapai peserta tes skor $_{\min }=$ skor minimum yang dicapai peserta tes.

\section{HASIL PENELITIAN DAN PEMBAHASAN}

Hasil pengembangan yang dilakukan oleh peneliti dalah perangkat pembelajaran yang meliputi, RPP, LKS dan THB. Prosedur pengembangan perangkat dalam penelitian ini menggunakan model 4-D dengan melakukan beberapa modifikasi, Penyederhanaan tahap pengembangan yang hanya terdiri dari tiga tahap, yaitu: (1) pendefinisian (define), perencanaan (design), dan pengembangan (develop). Jadi tidak sampai pada tahap penyebaran (disseminate) karena sampai pada tahap 3 sudah bisa dihasilkan perangkat yang dikehendaki.

Dari hasil setiap tahapan prosedur penelitian yang dilakukan adalah sebagai berikut:

a. Define

Dari hasil analisis keseluruhan diperoleh learning obstacle adalah sebagai berikut:

1) pertama kurangnya minat siswa di MTs Sirajul Huda untuk mengikuti pelajaran matematika dan siswa selalu beranggapan bahwa mempelajari matematika itu kurang bermanfaat dan sangat sulit.

2) guru merasa kesulitan dalam mengelola pembelajaran dengan implementasi kurikulum 2013 
DOI: https://doi.org/10.24127/ajpm.v8i2.1954

3) siswa kurang tertarik karena metode pembelajaran yang masih membingungkan dan membosankan bagi siswa serta banyaknya rumusrumus yang sulit diingat siswa dan ditambah dengan implementasi kurikulum 2013 guru hanya sebagai fasilitator dan hanya menggunakan bahan ajar yang masih sulit untuk dipahami.

4) Siswa menginginkan pembelajaran yang membuatnya menjadi lebih aktif, menyenangkan dan mudah diingat.

5) Input dari MTs Sirajul Huda sangat beragam oleh karena itu memerlukan waktu yang cukup lama untuk menerima pembelajaran.

Dalam learning obstacle dikemukakan oleh suryadi dalam Simanulang (2013) ada tiga jenis yaitu, Ontogenical learning obstacle, didatical learning obstacle, epistemelogical learning obstacle. Artinya kesulitan belajaran siswa disebabkan karena ketidaksiapan mental, kekeliruan penyajian dan sebuah konsep yang tidak lengkap.

Langkah-langkah penyusunan produk ini menyesuaikan dengan implementasi kurikulum 2013.

\section{b. Design}

Perancangan ini bertujuan untuk merancang perangkat pembelajaran untuk memperoleh draf awal, perangkat pembelajaran yang meliputi RPP, LKS dan THB yang natinya dapat membantu guru dan siswa dalam proses pembelajaran dan mengurangi hambatan guru dalam mengimplementasikan kurikulum 2013 dan mengurangi hambatan siswa dalam belajar sehinnga pembelajaran akan terasa lebih bermakna.

\section{c. Develop}

Kelayakan perangkat yang dikembangkan pada materi aritmatika sosial dinilai oleh 2 orang ahli yang terdiri dari 1 orang ahli desain atau ahli media, 1 oranga ahli materi, sedangkan untuk RPP dan THB di validasi oleh 2 orang validator terdiri dari dari 1 orang dosen matemtaika 1 orang guru matematika.

Validasi LKS dilakukan oleh dosen ahli materi dan ahli media dari jurusan pendidikan matematika STKIP PGRI Bangkalan dan seorang guru matematika dari MTs Sirajul Huda. Lembar penilaian LKS terdiri atas beberapa aspek yaitu kecukupan isi, ketepatan isi, kesesuaian dengan RME, Kriteria penerapan implementasi kurikulum 2013 dan Tampilan.

Tabel 2. Data hasil penilaian LKS oleh validator

\begin{tabular}{|c|c|}
\hline Aspek & $\begin{array}{c}\text { Skor } \\
\text { Rata-Rata }\end{array}$ \\
\hline Kecukupan isi & Baik \\
\hline $\begin{array}{l}\text { Ketepatan isi } \\
\text { Kesesuaian } \\
\text { dengan RME }\end{array}$ & $\begin{array}{l}\text { Sangat Baik } \\
\text { Sangat baik }\end{array}$ \\
\hline $\begin{array}{l}\text { Kriteria } \\
\text { implementasi } \\
\text { Kurikulum } \\
2013\end{array}$ & Baik \\
\hline Tampilan & Baik \\
\hline $\begin{array}{l}\text { Kelayakan } \\
\text { Penyajian }\end{array}$ & Baik \\
\hline $\begin{array}{l}\quad \text { Berd } \\
\text { diketahui ba } \\
\text { yang dikemb } \\
\text { baik dari do } \\
\text { aspek lainny } \\
\text { baik. Walal } \\
\text { penilaian de } \\
\text { dan baik, } \\
\text { bagian dal } \\
\text { diperbaiki se } \\
\text { coba. }\end{array}$ & $\begin{array}{l}\text { arkan pada Tabel } 2 \\
\text { va rancangan awal LKS } \\
\text { igkan dinyatakan sangat } \\
\text { aspek. Sedangkan dari } \\
\text { termasuk ke ketegori } \\
\text { un mendapatkan hasil } \\
\text { an kriteria sangat baik } \\
\text { asih terdapat beberapa } \\
\text { ingga layak untuk diuji } \\
\text { ingang perlu }\end{array}$ \\
\hline
\end{tabular}


DOI: https://doi.org/10.24127/ajpm.v8i2.1954

Tabel 3. Hasil Validasi Tes Hasil Belajar (THB)

\begin{tabular}{lllc}
\hline \multicolumn{2}{c}{$\begin{array}{c}\text { Rata-Rata Jumlah Semua } \\
\text { Aspek }\end{array}$} & $\begin{array}{c}\text { Nilai } \\
\text { Rata-Rata }\end{array}$ \\
\cline { 1 - 3 } Validator I & 35 & 3,8 & \multirow{2}{*}{3,5} \\
\hline Validator II & 30 & 3,3 & \\
\hline
\end{tabular}

Berdasarkan Tabel 3 diketahui bahwa hasil validasi THB mendapat nilai rata-rata 3,5 berada dalam kategori baik yang artinya layak diujicobakan.

Draft II merupakan perangkat pembelajaran yang telah diperbaiki berdasarkan masukan dari para validator yang kemudian diujicobakan di kelas VII MTs Sirajul Huda. Selanjutnya dilakukan uji coba untuk melihat kesesuaian waktu yang dibutuhkan dan melatih guru agar terampil menyajikan materi menggunakan perangkat pembelajaran berbasis RME. Uji coba melibatkan seorang guru matematika dan dua orang pengamat.

Kemudian data hasil ujicoba lapangan yang telah terkumpul dianalisis untuk menjadi bahan pertimbangan dalam merevisi Draft II. Berikut hasil analisis data uji coba.

1. Data Kemampuan Guru Mengelola Pembelajaran

Hasil pengamatan terhadap kemampuan guru mengelola pembelajaran dengan mengunakan perangkat pembelajaran berbasis RME dapat dilihat pada Tabel 4 di bawah ini.

Tabel 4. Hasil Pengamatan Kemampuan Guru Mengelola Pembelajaran

Aspek yang diamati Pert. 1 Pert. 2 Pert. 3

Pendahuluan:

Mengingat kembali materi prasyarat/ sebelumnya

Memotivasi siswa

Menyampaikan tujuan

pembelajaran

$\begin{array}{lll}4 & 3 & 4 \\ 4 & 3 & 3 \\ 3 & 4 & 4\end{array}$

Kegiatan Inti:

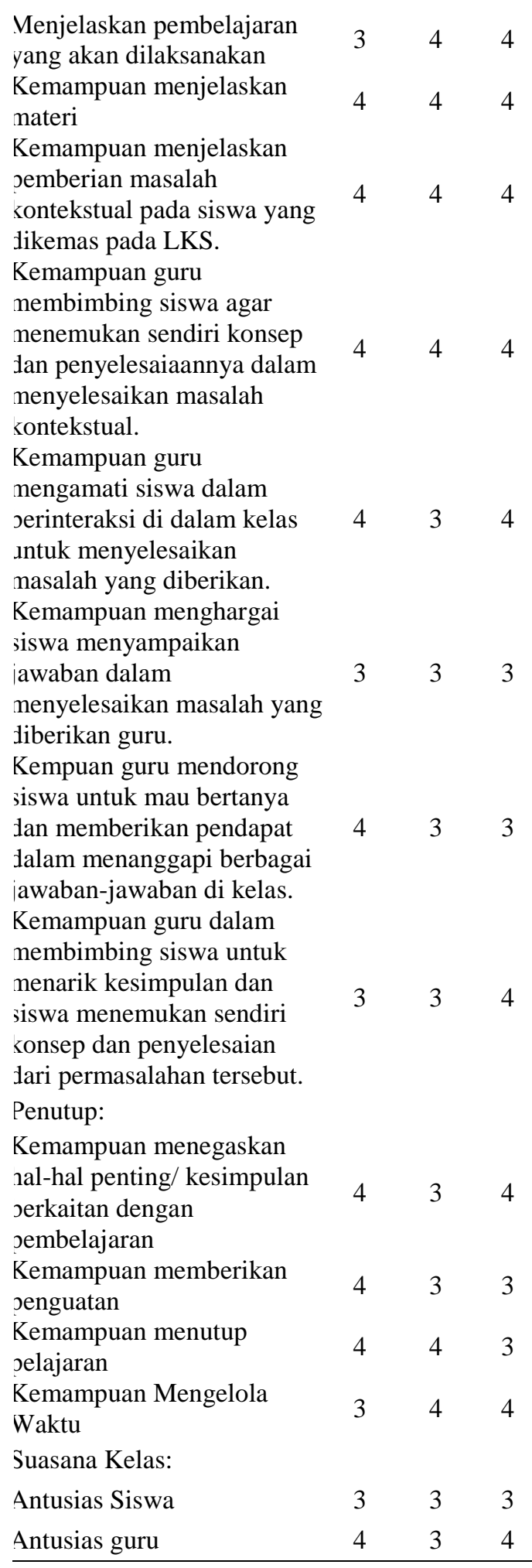

Pada Tabel 4 terlihat bahwa aspek menginformasikan kepada siswa tentang tujuan pembelajaran dan model pembelajaran yang akan dilaksanakan, aspek mengingatkan kembali materi 
sebelumnya dan memotivasi siswa tentang pentingnya pelajaran, aspek membimbing siswa dalam diskusi, aspek membuat kesimpulan dari hasil kegiatan pembelajaran, aspek bersama siswa membuat rangkuman materi yang telah dipelajari, dan aspek pengelolaan waktu berada pada kategori baik. Berdasarkan analisis data kemampuan guru mengelola pembelajaran, maka diperoleh kemampuan guru mengelola pembelajaran baik.

2. Data Aktivitas Siswa

Hasil pengamatan terhadap aktivitas siswa dalam pembelajaran selama tiga kali pertemuan dinyatakan dalam persentase. Kesimpulan hasil pengamatan disajikan pada Tabel 5.

Tabel 5. Hasil Pengamatan Aktivitas Siswa Kelas Uji Coba

\begin{tabular}{llccc}
\hline \multirow{2}{*}{ No Aspek Pengamatan } & \multicolumn{3}{c}{ Persentase Aktivitas } \\
\cline { 2 - 4 } & Siswa \\
\hline & $\begin{array}{l}\text { Memperthatikan } \\
\text { penjelasan guru dan } \\
\text { bertanya. }\end{array}$ & 17.70 & 18.75 & 19,79 \\
\hline 2 & & & \\
\hline 3 Membentuk kelompok & 6,25 & 6,25 & 6,25 \\
\hline 4 & 6,25 & 6,25 & 6,25 \\
\hline $\begin{array}{l}\text { Mengamati dan } \\
\text { mencermati } \\
\text { permasalahan yang } \\
\text { terdapat pada LKS. }\end{array}$ & 5.26 & 5.26 & 5.26 \\
\hline 5 & $\begin{array}{l}\text { Menyelesaikan } \\
\text { permasalahan atau } \\
\text { tugas pada LKS }\end{array}$ & 18,75 & 18,75 & 19,79 \\
\hline 6 & Siswa berdiskusi & 25 & 26,04 & 23,95 \\
\hline 7 & $\begin{array}{l}\text { Siswa } \\
\text { mempresenrasikan hasil } \\
\text { pekerjaannya }\end{array}$ & 17,70 & 15,62 & 18,75 \\
\hline 8 & $\begin{array}{l}\text { Perilaku yang tidak } \\
\text { relevan dengan } \\
\text { kegiatan pelajaran }\end{array}$ & 3,09 & 3,08 & 0,00 \\
\hline
\end{tabular}

Berdasarkan pada Tabel 5, semua aspek pada ketiga pertemuan berada dalam toleransi keefektifan. maka aktivitas siswa dikatakan aktif. Namun, dalam menerapkan pembelajaran di kelas khususnya membentuk kelompok, guru harus memperhatikan keheterogenan berdasarkan jenis kelamin. Hal ini sesuai dengan pendapat Sari, Budayasa \& Juniati (2017) bahwa dalam membentuk kelompok harus heterogen berdasarkan jenis kelamin, agar siswa saling berinteraksi satu sama lainnya.

\section{Data Respon Siswa}

Berdasarkan jawaban siswa yang tertuang dalam angket respon siswa diperoleh hasil sebagai berikut.

a. Perasaan siswa terhadap komponen mengajar

Tabel 6. Perasaan siswa terhadap komponen pengajaran

\begin{tabular}{ccc}
\hline \multicolumn{1}{c}{$\begin{array}{c}\text { Komponen } \\
\text { Mengajar }\end{array}$} & Setuju (\%) & $\begin{array}{c}\text { Tidak } \\
\text { setuju (\%) }\end{array}$ \\
\hline $\begin{array}{l}\text { Lembar Kegiatan } \\
\text { Siswa (LKS) }\end{array}$ & 96,7 & 3,33 \\
\hline
\end{tabular}

Tabel 6 menunjukkan bahwa sebagian besar siswa merasa senang dengan materi pelajaran, Lembar Kegiatan Siswa, suasana belajar di kelas, dan cara guru mengajar dengan menggunakan perangkat pembelajaran berbasis RME.

b. Pendapat siswa mengenai Lembar Kegiatan Siswa (LKS) dan Tes Hasil Belajar (THB)

Tabel 7. Pendapat siswa mengenai LKS dan THB

\begin{tabular}{|c|c|c|}
\hline Komentar Siswa & $\begin{array}{c}\text { Setuju } \\
(\%)\end{array}$ & $\begin{array}{c}\text { Tidak } \\
\text { setuju } \\
(\%)\end{array}$ \\
\hline $\begin{array}{l}\text { 1. Bahasa yang digunakan } \\
\text { dalam LKS dapat } \\
\text { dipahami }\end{array}$ & 80 & 20 \\
\hline $\begin{array}{l}\text { 2. Bahasa yang digunakan } \\
\text { dalam THB dapat } \\
\text { dipahami }\end{array}$ & 83,3 & 16,7 \\
\hline
\end{tabular}

Tabel 7 menunjukkan pendapat siswa terhadap bahasa yang digunakan dalam LKS maupun THB dapat dipahami.

c. Ketertarikan siswa terhadap Lembar Kegiatan Siswa (LKS) dan Tes Hasil Belajar (THB) 
DOI: https://doi.org/10.24127/ajpm.v8i2.1954

Tabel 8. Ketertarikan siswa terhadap LKS dan THB

\begin{tabular}{|c|c|c|c|}
\hline & Komentar Siswa & $\begin{array}{c}\text { Setuju } \\
(\%)\end{array}$ & $\begin{array}{c}\text { Tidak setuju } \\
(\%)\end{array}$ \\
\hline 1. & $\begin{array}{ll}\text { Penampilan } & \text { LKS } \\
\text { menarik } & \end{array}$ & 96,7 & 3,33 \\
\hline 2. & $\begin{array}{l}\text { Penampilan } \\
\text { menarik }\end{array}$ & 93,3 & 6,67 \\
\hline
\end{tabular}

Berdasarkan data pada Tabel 6, 7 dan 8 , ternyata jawaban siswa terhadap pernyataan adalah positif untuk setiap aspek yang direspon. Jadi respon siswa terhadap perangkat pembelajaran berbasis RME adalah positif. Hal ini sesuai pendapat Sari, Budayasa \& Juniati (2018) bahwa siswa menyukai sesuatu hal yang berwarna dan hal ini akan memicu semangat siswa untuk belajar.

4. Data Hasil Belajar

Data hasil belajar dianalisis untuk melihat validitas, sensitivitas, dan reliabilitas instrumen Tes Hasil Belajar (THB). Hasil perhitungan validitas setiap butir tes dengan menggunakan rumus korelasi product moment disajikan pada Tabel 9.

Tabel 9. Validitas Butir Tes

\begin{tabular}{cccc}
\hline No. Soal & 1 & 2 & 3 \\
\hline $\mathrm{r}_{\mathrm{xy}}$ & 1.05989 & 1.04379 & 1.1523 \\
Validitas & Tinggi & Tinggi & Tinggi \\
\hline No. Soal & 4 & 5 & 6 \\
\hline $\mathrm{r}_{\mathrm{xy}}$ & 1.09299 & 0.899885 & 0.909454 \\
Validitas & Tinggi & Tinggi & Tinggi \\
\hline No. Soal & 7 & 8 & 9 \\
\hline $\mathrm{r}_{\mathrm{xy}}$ & 1.01195 & 0.836782 & 0.598276 \\
Validitas & Tinggi & Tinggi & Cukup \\
\hline No. Soal & 10 & & \\
\cline { 1 - 2 } $\mathrm{r}_{\mathrm{xy}}$ & 0.642441 & & \\
Validitas & Cukup & &
\end{tabular}

Berdasarkan kriteria kelayakan butir tes yang terdapat pada Tabel 9, maka setiap butir tes dikategorikan valid. Hasil perhitungan sensitivitas setiap butir tes dengan menggunakan rumus indeks sensitivitas disajikan pada Tabel 10.
Tabel 10. Sensitivitas Butir Tes

\begin{tabular}{|c|c|c|c|}
\hline No. Soal & 1 & 2 & 3 \\
\hline$S$ & 0.56 & 0.52667 & 0.56333 \\
\hline Sensitivitas & Sensitif & Sensitif & Sensitif \\
\hline No. Soal & 4 & 5 & 6 \\
\hline$S$ & 0.56333 & 0.35 & 0.59333 \\
\hline Sensitivitas & Sensitif & Sensitif & Sensitif \\
\hline No. Soal & 7 & 8 & 9 \\
\hline$S$ & 0.5 & 0.58 & 0.62 \\
\hline Sensitivitas & Sensitif & Sensitif & Sensitif \\
\hline No. Soal & 10 & & \\
\hline$S$ & 0.5 & & \\
\hline Sensitivitas & Sensitif & & \\
\hline
\end{tabular}

Berdasarkan kriteria sensitivitas pada Tabel 10, semua butir tes dikategorikan baik.

Berdasarkan hasil perhitungan reliabilitas tes dengan menggunakan rumus Alpha, diperoleh koefisien reliabilitas 0,620391834. Berarti reliabilitas tes dikategorikan tinggi.

Berdasarkan uraian tentang hasilhasil ujicoba lapangan pada aspek kemampuan guru mengelola pembelajaran, aktivitas siswa, respon siswa dan butir soal dapat disimpulkan bahwa perangkat pembelajaran berbasis RME yang dikembangkan memenuhi kriteria yang baik. Kriteria tersebut dapat dilihat pada Tabel 11.

Tabel 11. Pencapaian Kriteria Perangkat Pembelajaran yang Baik

\begin{tabular}{cll}
\hline No & \multicolumn{1}{c}{ Aspek Kategori } & Keterangan \\
\hline 1 & $\begin{array}{l}\text { Kemampuan guru } \\
\text { mengelola }\end{array}$ & Baik \\
& pembelajaran & \\
2 & Aktivitas siswa & Aktif \\
3 & Respon siswa & Positif \\
4 & Butir soal THB & Valid, \\
& & Reliabel dan \\
& & Sensitif \\
\hline
\end{tabular}

Dengan terpenuhinya kriteria perangkat pembelajaran yang baik seperti pada Tabel 11, maka perangkat pembelajaran berbasis RME untuk materi aritmatika sosial yang telah diujicobakan menjadi perangkat final. Perangkat final tersebut meliputi Rencana Pelaksanaan Pembelajaran 
(RPP), Lembar Kegiatan Siswa (LKS), dan Tes Hasil Belajar (THB).

Hasil penelitian ini melengkapi hasil-hasil penelitian sebelumnya khususnya berkaitan dengan pengembangan perangkat pembelajaran berbasis RME. Artinya bahwa hasil penelitian ini telah menghasilkan perangkat pembelajaran berbasis RME pada materi aritmatika sosial.

Selain itu, hasil penelitian ini juga melengkapi hasil-hasil penelitian sebelumnya khususnya berkaitan dengan pengembangan perangkat pembelajaran pada materi aritmatika sosial. Artinya bahwa hasil penelitian ini telah menghasilkan suatu perangkat pembelajaran untuk mengajarkan materi aritmatika sosial dengan menggunakan pendekatan pembelajran RME.

Perangkat pembelajaran berbasis RME untuk mengajarkan materi aritmatika sosial merupakan produk yang dihasilkan dari penelitian ini. Produk ini dikatakan baik dan dapat digunakan oleh para paraktisi untuk mengajarkan aritmatika sosial. Kriteria baik untuk produk hasil penelitian ini pada langkah develop didasarkan pada kemampuan guru dalam mengelola pembelajaran, aktivitas siswa, respon siswa yang menunjukkan kriteria baik. Hal ini sesuai dengan hasil penelitian Amrullah (2014) yang menghasilkan bahwa penerapan pendekatan RME yang dapat meningkatkan hasil belajar siswa kelas VII MTsN Palu Barat dalam menyelesaikan soal cerita tentang himpunan mengikuti langkah-langkah sebagai berikut: (1) memahami masalah kontekstual, (2) menyelesaikan masalah, (3) membandingkan dan mendiskusikan jawaban,

menyimpulkan. Keberhasilan penerapan pendekatan RME dalam meningkatkan hasil belajar siswa ini tidak terlepas dari peran guru dalam mengelola pembelajaran. Sehingga jika kemampuan guru dalam mengelola pembelajaran baik, maka aktivitas siswa akan terarah. Aktivitas siswa terarah, maka siswa akan semangat dalam mengikuti pembelajaran. Hal ini akan mengakibatkan respon siswa positif.

Proses penelitian ini sejalan dengan proses penelitian yang dilakukan oleh Murwaningsih, Astutiningtyas \& Rahayu (2014) bahwa model pengembangan perangkat yang digunakan adalah model 4D yang dimodifikasi menjadi 3 langkah yaitu define, design dan develop. Hal ini dikarenakan di tahap develop, telah memperoleh perangkat pembelajran yang baik. Begitu pula hasil penelitian Murwaningsih, Astutiningtyas \& Rahayu (2014), telah mengembangkan perangkat pembelajaran berbasis RME berupa RPP, Buku siswa, LKS, Buku petunjuk guru dan perangkat tes hasil belajar siswa. Hanya saja perangkat pembelajaran yang telah dikembangkan untuk mengajarkan materi aljabar. Sedangkan perangkat pembelajaran yang telah dikembangkan dari hasil penelitian ini untuk mengajarkan materi aritmatika sosial. Hal ini menunjukkan bahwa penelitian ini menyempurnakan beberapa hasil penelitian sebelumnya berkaitan dengan pengemabangan perangkat pembelajaran berbasis RME.

\section{KESIMPULAN DAN SARAN}

Hasil penelitian ini adalah diperoleh perangkat pembelajaran berupa RPP, LKS dan Soal THB berbasis RME yang baik pada materi aritmatika sosial. Perangkat pembelajaran tersebut dikatakan baik dan valid karena pada tahap develop diperoleh: (1) kategori efektif untuk kemampuan guru mengelola pembelajaran, (2) kategori efektif untuk aktivitas siswa dalam pembelajaran, (3) 
kategori positif untuk respon siswa terhadap perangkat pembelajaran, dan (4) memenuhi kategori validitas, reliabilitas dan sensitivitas untuk THB. Adapun perangkat pembelajaran yang dihasilkan meliputi Rencana Pelaksanaan Pembelajaran (RPP), Lembar Kegiatan Siswa (LKS), dan Tes Hasil Belajar (THB).

Berdasarkan hasil penelitian, dikemukakan saran bahwa perangkat pembelajaran matematika yang dihasilkan di dalam penelitian ini dapat digunakan sebagai perangkat pembelajaran alternatif oleh guru dalam membelajarkan materi aritmatika sosial pada kelas VII SMP/MTS untuk meningkatkan hasil belajar siswa. Sedangkan bagi peneliti selanjutnya dapat melihat efektivitas pembelajaran dengan menggunakan perangkat ini denagn melakukan uji coba di sekolahsekolah dengan berbagai kondisi sehingga diperoleh perangkat yang lebih baik, karena penelitian pengembangan ini dilakukan hanya sampai pada tahap ketiga (Develop).

\section{DAFTAR PUSTAKA}

Musyaddad, K. (2013). Problematika Pendidikan di Indonesia. Jurnal edo-bio, 4(1), 51-52

Murtiyasa, B. (2015). Tantangan Pembelajaran Matematika Era Global. Prosiding seminar nasional matematika dan pendidikan matematika UMS 2015, 28-47

Sarismah. (2012). Penerapan Realistic Mathematic Education (RME) Untuk Meningkatkan Prestasi Belajar Siswa Pada Materi Segitiga Kelas VII-H SMP Negeri 7 Malang. Diunduh dari http://jurnalonline.um.ac.id/data/artikel/artikel0 9615885D322CBF4AD13CBA4C6 BA092E.pdf [21 September 2019]
Simanulang, J. (2013). Pengembangan Bahan Ajar Materi Himpunan Konteks Laskar Pelangi dengan Pendekatan Realisthic Mathematics Indonesia (PRMI) Kelas VII Sekolah Menengah Pertama. Jurnal Pendidikan Matematika, 8(1), 2536.

Ningsih, P. R. (2013). Penerapan Metode Realistic Mathematics Education (RME) Pada Pokok Bahasan Perbandingan Senilai dan Berbalik Nilai di kelas VII E SMP Ipiems Surabaya. Jurnal Gamatika, 3(2), 177-184

Sari, D. I. \& Hermanto, D. (2017). Development of Probabilistic Thinking-Oriented Learning Tools For Probability Materials At Junior High School Students. AIP Conference Proceedings, 1867(1), 020042

Murwaningsih,U., Astutiningtyas, E. L., \& Rahayu, N. T. (2014). Implementasi Pengembangan Perangkat Pembelajaran Matematika Realistik di Sekolah Menengah Pertama. Cakrawala Pendidikan Jurnal Ilmiah Pendidikan, 33(3), 463-473

Azizah, I. N. (2017). Lembar Kerja Peserta Didik Materi Aritmatika Sosial dengan Model Pengembangan Thiagarajan. Numerical: Jurnal Matematika dan Pendidikan Matematika, 1(2), 6372

Sari, D. I. (2015) Pengembangan Perangkat Pembelajaran Kooperatif Tipe TPS Pada Materi Persamaan Kuadrat Kelas X. Jurnal Pendidikan, 7(1), 72-83.

Sari, D. I, Budayasa, I.K \& Juniati, D. (2017). Probabilistic Thinking of Elementary School Students In Solving Probability Tasks Based on 
DOI: https://doi.org/10.24127/ajpm.v8i2.1954

Math Ability. AIP Conference

Proceedings, 1867(1), 020028

Sari, D. I, Budayasa, I.K \& Juniati, D.

(2018). Analisis Penyelesaian

Tugas Probabilitas Siswa SD

Ditinjau dari Perbedaan

Kemampuan Matematika dan

Gender. Jurnal Aksioma Program

Studi Pendidikan Matematika, 7(1), 124-139.

Amrullah, A. L. (2014). Penerapan

Pendekatan Realistic Mathematics

Education Untuk Meningkatkan

Hasil Belajar Siswa Pada Materi

Soal Cerita Tentang Himpunan Di

Kelas Vii Mtsn Palu Barat. Jurnal

Elektronik Pendidikan Matematika

Tadulako, 2(1), 1-11. 